\title{
$\begin{array}{llllllllllllllll}U & W & A & G & I & I & W & \text { I } & A & D & 0 & M & 0 & 5 & C & \text { I }\end{array}$
}

\author{
O. Augustyn Jankowski OSB
}

\section{SESJA PLENARNA PAPIESKIEJ KOMISII BIBLIJNEJ W RZYMIE}

Mianowany w 1984 roku na lat pięć przez Ojca św. Jana Pawła II nowy zespół Papieskiej Komisji Biblijnej odbył pierwszą swoją sesję plenarną $\mathrm{w}$ dniach od 15 do 19 kwietnia 1985 r. Spośród 20 czlonków nie przybyli na nią z powodu choroby: P. Benoit OP, P. Grelot i J. Schreiner. Zainaugurował, a potem zakończył sesję Kard. Josef Ratzinger, Prefekt Kongregacji Doktryny Wiary, Prezes Komisji. On też gremium członków przedstawił Ojcu św. na specjalnej audiencji w dniu 18 kwietnia. Podczas tej audiencji Kard. Ratzinger w przemówieniu wstępnyn uvyantnił trudność zadań, jakie ma przed sobą obecnie Komisja, oraz zarysował temat prac jej $\mathrm{w}$ ciągu najbliższych 4 lat - związek Kościołów lokalnych $\mathrm{z}$ powszechnością jedynego Ludu Bożego. W odpowiedzi Ojciec św. podkreślił dwie cechy, jakimi winny się odznaczać prace Komisji Biblijnej: dokładnością naukową i integralnością wiary oraz zaznaczył, że powyższy temat ma być pogłębieniem tej nauki, którą zawiera nr 26 Konstytucji Soborowej „Lumen gentium”. W końcowej części allokucji padła z ust Ojca św. także przestroga: ,ut accurate secernatis textus S. Scripturae a doctorum coniecturis, tum vestris tum aliorum". Po udzieleniu błogosławieństwa Papież przywitał się ze wszystkimi obecnymi członkami Komisji, wręczając każdemu pamiątkowy album z Roku Jubileuszowego w Rzymie. Nad pracami gremium i podkomisji czuwał Sekretarz H. Cazelles PSS (Paryż).

Kraków - Tyniec

O. AUGUSTYN JANKOWSKI OSB

Ks. Serzy Chmiel

\section{COLLOUIUM BIBLICUM W WIEDNIU 1934}

W dniach 19-20 października 1984 r. odbyło się w Wiedniu już trzecie z rzędu Colloquium Biblijne na temat: „Oczekiwanie przyszłości. Biblijne modele wartościowania życia". Colloquium to zgromadziło około 40 egzegetów z Austrii, NRD, Czechosłowacji, Polski, Wegier, Rumunii i Jugosławii. Z Polski uczestniczyło 6 biblistów.

Obrady otworzył odczytem gościnnym J. MI arbö $k$ z Grazu nt. „W horyzoncie lęku Bożego. Aspekty świata i życia w starotestamentalnej literaturze mądrościowej" (zob. opublikowane w BN 26, 1985, ss. 47-70). Prelegent wyróżnił następujące aspekty: 1. troska o pozytywne strony życia we wszystkich dziedzinach, 2. stworzenie jako wyraz stosunku Boga do człowieka, 3. lęk Boży (= cześć Boga) jako punkt wyjścia wszelkiej mądrości. 